\title{
Business Ethics in Islamic Finance
}

\author{
Naif Mansour M. Mathkur \\ Business College, Jazan University, \\ Jazan, Kingdom of Saudi Arabia
}

\begin{abstract}
The goal of this research undertaking is to provide illuminating insights on the phenomenon of business ethics in Islamic finance. The paper offers insight into the ways that Islamic finance can enhance the upholding of utmost business ethics in diverse settings. For this, the study employees a meticulous literature review that covers an array of credible primary, secondary, and tertiary sources. This research dissemination finds that many players in the Islamic finance segment observe business ethics in general. Scores of Islamic finance practitioners observe the business ethics laid out in the Shari'ah. However, there are quite a few notable cases of wayward participants who have not been true to business ethics. The results of deviation from ethical business practices have been catastrophic. To deepen the observance of business ethics, it is important for the Islamic finance industry to deploy pragmatic and objective models that can be timely applied to warn of possible deviation from the observance of the ethical ideals laid out in the Shari'ah and avert the possible adverse consequences. The paper is tentative in nature. There is a need for further empirical research.
\end{abstract}

Keywords: Islamic banking and finance, ethics, business ethics, non-interest financing.

\section{INTRODUCTION}

Islam is a way of life. Ethics lie at the heart of Islam. The entire Islamic law places a premium on ethical conduct in all the affairs of man in this world. The Shari'ah is inseparable from ethics. Ethics in an Islamic system differ from that of a conventional system as ethical ideals, theories and practices in the former are shaped by reverence to Allah (SWT) while in the latter ethics are based on transitory customs. Islamic ethics are based on the eternal provisions revealed to man from the Holy Quran and the Sunnah teachings of Prophet Mohammed (peace be upon him). The concept of Mașlahah, or social welfare or utility ("common good"), is at the heart of the fundamental decrees of Islam. The ideal of Mașlahah touches on all human affairs including business - and defines the nature of the proper links and relationships between individuals and the society (Montgomery, 2010). Mașlahah is the building block of all the business ethics of Islamic finance.

Ethics in business have attracted growing interest due to the growing disillusionment with the race for materialism at all gains that is popular in most aspects of the conventional society. The nadir of the observance of business ethics in the conventional financial system is highlighted in history by the global credit crunch of 2008 . The credit crisis was precipitated by the rampant unethical practices of the various participants in the conventional financial system despite there being supervisory and regulatory authorities.

Islamic finance is as old as Islam itself (Al Rayan Bank, 2015). With historical roots tracing well into the 7th century, Islamic finance has grown in leaps and bounds to become dominant player in the global financial services sector. Islamic finance is the fastest growing segment of the global financial services market. It has remained true to the guiding principles of the Shari'ah (Al Rayan Bank, 2015). Islamic finance in its pure form is devoid of speculation and excessive uncertainty. It is built upon the principles of trade, entrepreneurship, and risk 
sharing (Al Rayan Bank, 2015). These ideals strengthen the relationship between Islamic financial institutions and their customers while at the same time stimulating increasing the scale of economic activities and opportunities for individuals, organizations, and the greater society (Al Rayan Bank, 2015).

The formation of Islamic finance businesses is ethical since they are based on the principles of the Shari'ah. The Holy Quran offers, "'It is no crime in you if ye seek of the bounty of your Lord (by trading)" (Al- Baqrah (2):198). The Prophet Salla Allahu alai wa sallam was a honest, successful, and ethical businessperson. Dignified business promotes the virtues of selfachievement, success, self-reliance, hard work, decency, and integrity. Islamic finance institutions apply ethical and society-friendly criteria in the management and administration of the affairs. (Wilson, 1997). According to Islam, only the morally upright are complete in faith (Alaro, 2009). Business activities that generate genuine profits are fully permissible in Islam. For every permissible act under the Shari'ah, there are germane rules to be followed. The rules take the form of mandatory conditions to be observed (Shurūt) or impediments (Mawāni) that have to be avoided (Alaro, 2009). The absence of the former all the presence of the latter could render an act null and void for being unethical under the Shari'ah (Alaro, 2009).

Some Islamic finance institutions have gone ahead to bag awards due to their outstanding observance of business ethics when pit against their contemporary Western peers. For instance, the Ethical Consumer Magazine ranked the Al Rayan Bank (formerly known as the Islamic Bank of Britain) as being among the top ten current account providers in the world (Al Rayan Bank, 2015).

\section{THE TENETS OF BUSINESS ETHICS IN ISLAMIC FINANCE}

In the context of business ethics in Islamic finance, there are those ethical notions that are characteristically underpinned in religion while others generally bear semblance to the ethical ideals and practices espoused by the conventional system. The unique business ethics of Islamic finance touch on the absence of Riba in transactions; the avoidance of Haram activities; non-participation in excessive risk-taking and speculative activities; prohibition in dealing with forbidden items such as alcohol, pork, and pornography. Montgomery (2010) pinpoints that the business ethics in Islamic finance are hinged on the promotion of trade and cooperation; prohibition of Ribā and of profiting without risk; the prohibition of gharar and maysir; and the requirement of charity and altruistic acts.

Islamic business ethics hold that enterprises of any nature exist to create value to all the stakeholders. Allah (SWT) is a stakeholder in any business endeavor since God created people to carry out acts and hold ideas that seek God's pleasure. Prophet Mohammed (peace be upon him) impressed upon the importance of ethics to his followers in business in several Sunnahs. The Prophet (peace be upon him) was a businessman before his call to prophethood. Those who conduct business in a fair and ethical manner will share in the feast of the great saints in the Hereafter.

The business ethics of Islamic finance institutions are based on the commandments (Ahkam) of the Shari'ah. The Ahkam are derived from the Quran; the prophetic traditions; Ijma, the consensus of Islamic scholars and (iv) Qiyas, that is solving emerging issues by finding their analogies in the first three sources (Ullah, Jamali, \& Harwood, 2014). The business ethics drawn from the above sources clearly highlight the obligatory (Fardh and Wajeb); the recommended (Mandoob); the permitted (Mubah); the disliked (Makrooh); and the prohibited (Haram) (Ullah, Jamali, \& Harwood, 2014). The Fardh and Wajeb are the decrees sourced from the Holy Quran and the prophetic traditions that permit the obligative commission of specified 
acts. The performance of Fardh and Wajeb is rewarded while non-observance is punished (Ullah, Jamali, \& Harwood, 2014). For instance, commitment to Zakat deductions is a Fardh for the inidividuals participating in the Islamic finance transactions, the Muslim owners of the Islamic finance institutions, and the account-holders but not to the Islamic financial institutions themselves (Ullah, Jamali, \& Harwood, 2014). The Mandoob are directives regarding the performance of recommended actions and behaviors. Acting out on the Mandoob merits rewards while the non-performance of Mandoob is not punishable. An example of Mandoob in the business ethics of Islamic finance is with regard to the payment of high wages that exceed the maket rate; or the provision of good working conditions. While the payment of wages at rates that are higher than the market rate is not compulsory, it's non-commission is not punishable. The Mubah directives provide guidance on which actions and behaviours that Muslims can partake without any restrictions. For instance, the beneficial harnessing of natural resources is permitted to all Muslims provided that they do not degrade the environment. Acts of abuse of natural resources would make such activities Haram. The Makrooh deals with the actions and behaviors that are strongly disliked, discouraged, and loathesome. For instance, smoking is a destable act, but nevertheless it is not punishable. Issues that deal with whether it is ethical for Islamic finance institutions to fund the operations of companies that manufacture cigarettes and other tobacco products that are harmful to human health falls under the jurisdiction of Makrooh. Haram denotes those actions, practices, and behaviours that are completely outlawed by the Shari'ah. The consumption of intoxicants, participation in gambling, charging of Riba, divination, and speculation activities is Haram (Ullah, Jamali, \& Harwood, 2014). In the matter of Haram, the Holy Quran counsels, "0 ye who believe! Intoxicants and gambling, (dedication of) stones, and (divination by) arrows, are an abomination, of Satan's handiwork: Eschew such (abomination), that ye may prosper. Satan's plan is (but) to excite enmity and hatred between you, with intoxicants and gambling, and hinder you from the remembrance of Allah, and from prayer: Will ye not then abstain?" (AlMaida (5): 93-94). Haram activities and practices degrade the holistic development of a person and the society at large. All Haram actions are unethical and participants in Islamic finance activities should give them a wide bearth. According to Islamic finance, running conventional Western bank savings and investment deposits, purchasing interest yielding bonds, and the financing of institutions involved in alcohol production or the distribution of pork products is Haram (Wilson, 1997).

\section{Consciousness of God and Observance of the Shari'ah}

According to Islam, there is oneness, unity, and supremacy of the Almighty Allah (SWT). Allah (SWT) is the sole creator of heaven and the entire universe. Allah created the world and placed people in it to as his vicegerents. Businesses that uphold the supremacy of God and more likely to uphold business ethics as compared to those secular businesses do not incorporate reverence of God in their operations.

It is impossible to comply with the Shari'ah and be unethical in any undertaking in life. Shari'ah and ethics are strongly entwined. It is practically impossible to separate the two. Therefore, it goes without saying that, all the business ethics in Islamic finance have their roots in the Shari'ah. All Islamic financial institutions are supposed to comply with the Shari'ah from their formation as well as through their entire existence. In as much as there is no one single codified source of business ethics, all the implied ethical principles, and guidelines that govern the conduct of Islamic finance can be traced directly to the Holy Quran and the Sunnah teachings of the Prophet (peace be upon him). There is not one business ethics tenet of Islamic finance that emanates from secular sources. 
Al-Ghazali in Ihya-ulum-al-Dīn links economic performance within business arrangements to the promotion of the welfare of the society through the pursuit of the five-fold goals of Shari'ah (Maqasid al-Shari'ah) i.e. religion (dīn), life (nafs), progeny (nasl), property (māl), and reason ('aql) (Montgomery, 2010). All business ethics in Islamic finance should be geared towards safeguarding the above mainstays.

\section{Avoidance of Riba}

One of the remarkable distinguishing features of Islamic finance is the prohibition of Riba. The Holy Quran provides that, "Those who devour usury will not stand except as stand one whom the Evil one by his touch Hath driven to madness. That is because they say: "Trade is like usury," but Allah hath permitted trade and forbidden usury. Those who after receiving direction from their Lord, desist, shall be pardoned for the past; their case is for Allah [to judge]; but those who repeat [The offence] are companions of the Fire: They will abide therein [for ever]" (Al-Baqrah (2):275).

According to Islam, money has no intrinsic value. It is simply a measure of wealth, a medium of exchange, and a store of value. Therefore, money is not a commodity and the making of profit through the charging of Riba is forbidden. Due to the prohibition of usury, deposit taking Islamic financial institutions and individuals are expected to invest the money in prudent as well as legitimate wealth generation and accumulation ventures. The money collected through savings accounts or similar deposit taking facilities offered by Islamic finance institutions do not earn interest but 'expected profit'. The 'expected profit' acts as a performance target set by the Islamic finance institution. The Shari'ah scholars appointed by the shareholders oversee that Islamic finance institutions do not set a low lackadaisical targeted rate of 'expected profit'. The rates quoted to the depositors of funds by the Islamic finance institutions represent the expected rate of return on the investment of the funds in Shari'ah-compliant legitimate economic undertakings. Due to the element of risk, the actual profit paid out to the depositor of the fund by the deposit-taking Islamic finance institutions may turn out to be higher or lower than the quoted 'expected profit'. Where possible, Islamic finance institutions should try to maximize the returns that they offer to their clients - the depositors. It is not uncommon to find Islamic banks that often exceed the expectations of their clients and offer actual profits that exceed the expert-valued 'expected profits' due to sound investment decisions, policies, and activities (Al Rayan Bank, 2015).

According to Islam, the element of usury promotes financial inequity and social injustice in financial dealings (Al Rayan Bank, 2015). Islam outlaws profits that are made without effort or risk to the lender as such returns connote money being made from money and this is unethical given the correct purpose of money (Montgomery, 2010).

\section{Integrity}

According to the underpinning Shari'ah guidelines that govern or Shari'ah compliant business and Islamic finance activities, all the parties to economic and financial dealings are supposed to observe integrity by upholding truthfulness, honesty, virtue, and decency in their conduct. The Holy Quran asserts that, “"O ye who believe! Fulfill (all) obligations.” (Al-Māidah (4): 1)”. All the parties to Islamic finance transactions and dealings should keep their end of the bargain. On this matter, the Holy Quran counsels, "And fulfill (every) covenant, for (every) covenant will be enquired into [on the Day of Reckoning]"Al-Isrā' (17): 34. The Holy Quran adds that "Those who faithfully observe their trusts and their covenants ... these will be the heirs, who will inherit Paradise: they will dwell therein [for ever]" (Al-Mu'minūn (23): 8, 10-11). 
A Muslim is at liberty as to whether to enter into a contract or not, but once (s)he has expressed his/her words of commitment to a contractual arrangement, it becomes binding and must be fulfilled. The Prophet (Salla Allahu alai wa sallam) said, "Muslims are bound by their stipulations (Alaro, 2009)". Concerning the successful Mu'minūn, Allah says, "(They are) those who faithfully observe their trusts and their covenants" (Al-Mu'minūn (23): 8).

\section{Nonmaleficence}

All business surrounding Islamic finance affairs should be conducted in a manner that does not cause harm to other people. In the context of Islamic finance, the funding of those activities that can jeopardize the well-being of austerity all the wider society should not be carried out. Avoidance of uncertainty (Gharar) and gambling (Maysir) is aimed at protecting the other parties with stakes in Islamic finance transactions. Excessive speculation, uncertainty, and gambling is injurious to the best interests of the investors who put their hard-earned money in funding Islamic finance institutions. Additionally, partaking of activities with uncertainty and gambling can bring harm to the individual perpetrating such acts through addiction to unwholesome habits and eventual financial ruin.

All legal and ethical Islamic finance activities are supposed to be asset-based and asset-backed to safeguard the interests of all the parties. Conventional Western financial instruments like futures, derivatives, and options that are not backed by real assets are prohibited. The barring of such instruments from the scene of Islamic finance is necessary since they do not promote the holistic growth and development of the parties involved and the society at large. Additionally, due to the absence of backing by real assets, financial instruments contain elements of great speculation and excessive risk that are not permitted by the basic principles of Islam.

\section{Beneficence}

According to this ethical tenet, all economic activities should be conducted in a fashion that benefits all the parties to the transaction, as well as the wider society in general. This can be achieved by ensuring that all dealings are carried out in a way that ensures the realization of the Maqasid al-Shari'ah (Montgomery, 2010). Beneficence can be maximized by always choosing the best option that avails maximum return to all the interested stakeholders while not violating the principles of Shari'ah.

\section{Observance of the National Regulations and Local Operating Laws}

Some Islamic finance institutions operate in routines that have dual banking national financial systems. A number of Islamic finance institutions operate in environments where by the conventional Western banking and finance is the dominant segment of the financial system. In these environments, it is not uncommon to find interest rates being more pronounced by the players in the financial system as well as by regulatory authorities. In such cases, Islamic institutions may be required to express in percentage points the rates of their charges. Such quotations facilitate customers to make informed comparisons between the charges of Western conventional banking and finance institutions and those charged by the Islamic finance institutions. While such kind of rules may appear to bend towards the conventional Western finance system, Islamic banks ought to comply with certain legal and regulatory provisions. Islam is a religion of peace. Islam finance institutions need to exist harmoniously with their conventional Western peers and strive to uphold tranquility by complying with laws that do not fundamentally threaten compliance with the Shari'ah. In such regimes, Islamic finance institutions need to observe the national laws and regulatory regulations. They need to be transparent and impress upon the local Muslim population and the members of the investing public that expressing the rental rates as a percentage of the charge does not mean 
that it is converted into interest. Rather, the quoted percentage rate indicates how much rental expenses the Islamic finance institution charges the clients as a proportion of the property purchase price (Al Rayan Bank, 2015). While the interest-free loans of Islamic finance institutions are Shari'ah compliant and the conventional mortgages and loans are not, the percentage rate offers the measuring and comparison tool. Discrepancies between the ideal Islamic practices and the regulatory requirements should be solved in an amicable, peaceable, and cordial manner.

\section{BUSINESS ETHICS MATTERS CONCERNING THE VARIOUS PARTICIPANTS AND PEOPLE RELATIONSHIPS IN ISLAMIC FINANCE}

\section{The Employees and Employers}

The Hadith narrated by Imam Bukhari provides excellent guidelines on the defining characteristics and nature of the relationship between an employer and the employees. The Hadith goes as follows, "Al-Ma'rūr narrated saying, I met Abū Dharr" who was wearing a cloak, and his slave too wearing a similar one. I asked him about the reason for that, and he replied, I insulted someone by calling his mother with bad names. The Prophet (Salla Allah alayhi wa sallam) said to me, O Abū Dharr! Did you insult him by calling his mother bad names? You have in you some characteristics of ignorance. Your servants are your brothers whom Allah has put under your command. So whoever has his brother (as servant, slave, employee etc) under his command, he should feed him of what he himself eats, and cloth him of what he himself wears. Do not order them (your servants, slaves, employees etc.) to do what is beyond their capacity, and if you must do, then assist them" (Alaro, 2009). Employees should be treated with decency and dignity by their employers and superiors.

Many Islamic banks put the best interest of their employees at the forefront of their operations. When it comes to remuneration, Islamic financial institutions go beyond paying the compulsory minimum wage and the market wage levels. They choose to voluntarily pay a 'Living Wage' that is substantially higher than the compulsory minimum wage and average market wage (Al Rayan Bank, 2015).

A number of Islamic banking and finance institutions are 'Investors in People' (Al Rayan Bank, 2015). As exemplary employers, they support the empowerment of employees in all possible ways as they discharge their mandate.

The Holy Quran guides that, "Allah commands you to render back the trusts to those to whom they are due"(Al-Nisā' (4): 58). Employees should avoid defrauding their employers by robbing off the valuable time of the respective corporations that they work for. Employees should avoid tardiness and laziness at work at all time. Employees who do not work diligently get paid unearned income. The receipt of unearned work is forbidden in the Holy Quran. The unearned income is tantamount to the earning of Riba. Employees should take the initiative to improve their capacity for service delivery by sharpening their skills through commitment to lifelong learning of their craft. Furthermore, employees should avoid taking intoxicants or making poor lifestyle choices that diminish their productivity, effectiveness, and efficiency at work.

\section{The Management and Investors}

The management owe a critical duty of care to the investors. The investors appoint the board of directors and management as the stewards of their capital. The management should never engage in Gharar and Maysir. While speculation and excessive risk-taking practices may pay off in the short-term, they are detrimental to the long-term interests of the investors since they pose going concern threats to the business of the investors. 


\section{The Lenders and Borrowers}

The Holy Quran provides that "If the debtor is in a difficulty, grant him time till it is easy for him to repay. But if ye remit it by way of charity, that is best for you if ye only knew."(AlBaqarah (2): 280). The lenders should accommodate the exigencies of the borrowers in a compassionate manner. When the borrowers face genuine difficulties in repaying the loaned amounts, the lenders should reschedule the loan repayments without charging interest.

"To the Madyan People [We sent] Shu'aib, one of their own brethren: he said: "0 my people! worship Allah: Ye have no other god but Him. And give not short measure or weight: I see you in prosperity, but I fear for you the penalty of a day that will compass [you] all round. And 0 my people! give just measure and weight, nor withhold from the people the things that are their due: commit not evil in the land with intent to do mischief. That which is left you by Allah is best for you, if ye [but] believed! But I am not set over you to keep watch! ... When our decree issued, we saved Shu'aib and those who believed with him, by [special] mercy from ourselves: But the [mighty] blast did seize the wrongdoers, and they lay prostrate in their homes by the morning,- As if they had never dwelt and flourished there! Ah! Behold! How the Madyan were removed [from sight] as were removed the Thamud!" (Hūd (11): 84-86, 94-95). The above extract from the Holy Quran teaches that the lenders have to avail to the lenders the services that they promise to deliver. Islamic finance institutions should offer products and services in the manner, terms and conditions posed in advertising and other product promotion activities. Islamic finance institutions have an obligation to live up to their promises and satisfy the needs of their clients in the pledged manner. The Islamic finance institutions should not underdeliver services as the Holy Quran asserts that, "'Woe to those who deal in fraud. Those who, when they have to receive by measure from men, demand full measure. But when they have to give by measure or weight to men, give less than what is due" (Al-Mutaffifiin (83): 1-3). These stipulations prohibit the perpetration of pyramid schemes in Islamic finance.

The borrowers have an obligation to commit to the repayment of the loaned amount. Reckless spending of the loan extended to them jeopardizes the best interests of the lender. Borrowers should not take up loans that they know that they cannot afford to repay since this poses moral hazard problems to the lending Islamic finance institution. Borrowing a loan that one cannot pay in full according to the stipulated terms and conditions is unethical. It is ranked with the outlawed act of stealing.

\section{CASES OF NON-OBSERVANCE OF BUSINESS ETHICS}

There have been a few errant Islamic finance corporations that have failed to uphold Islamic ethical ideals in their operations. The adverse consequences of non-compliance with the business ethics by the delinquent Islamic banking and finance institutions shows that it is important to supervise, monitor, and follow-up Islamic financial institutions with regard to the strict adherence to the business ethics laid out in the Shari'ah. A brief discussion of some of the Islamic banking and finance institutions that went under due to engaging in wayward unethical practices follows.

The Islamic Bank of South Africa collapsed in 1997 (Nathie, 2009). Unethical business ethics were at the heart of the downfall of the Islamic Bank of South Africa. Investigations conducted on the operations of the collapsed Islamic Bank of South Africa revealed that the management of the bank accumulated Riba-based property debt in contravention to the blueprint for the ethical charter of Islamic banking and finance institutions laid out in the Shari'ah (Nathie, 2009). To cover up its malpractices, the bank resulted to using misleading, unethical, and unjust creative accounting (Nathie, 2009). 
The Islamic International Bank of Denmark faced severe operating bottlenecks that nearly brought it to its knees. Between 1985 and 1986, excessive risk-taking practices shaved off more than $30 \%$ of the equity of the Islamic Bank of Denmark (Grais, 2004).

The Ihlas Finance House in Turkey collapsed in 2002. The collapse of the Ihlas Finance House is deemed by some Islamic scholars and observers to be the biggest failure of an Islamic banking and finance institution. Risky lending and unethical practices precipitated the collapse of the Ihlas Finance House (Ali, 2007).

\section{RECOMMENDATIONS}

While most Islamic finance institutions are on the right pedestal when it comes to upholding business ethics, there are some Islamic finance entities that beat the corners in the observance of business ethics and full compliance with the Shari'ah. To thought of the risk of possible nonobservance of business ethics, the Islamic finance industry should embrace prediction models that do not flout the fundamental provisions of the Shari'ah. Failure prediction models are very common in the conventional Western banking and finance system. However, there is a notable absence of models that can predict the possible failure of Islamic finance institutions based on such criteria as observance of business ethics and compliance with the Shari'ah. Such predictive models that have reverence for the Shari'ah would be instrumental in pinpointing and averting cases of non-observance of business ethics in Islamic finance institutions.

Additionally, it is important to extinguish the confusion that surrounds certain Islamic finance situations. It is imperative for Islamic finance to issue clear authoritative pronouncements on whether the funding of food retailers, airlines, hotel enterprises, and accommodation institutions that there are a proportion of their revenue from alcohol sales is legal from a Shari'ah compliant point of view, or whether such businesses should be classified with breweries can excluded from any funding by Islamic finance institutions. Unambiguous guidelines should be codified and provide clarification whether it is ethical to fund lucrative business undertakings that derive insubstantial earnings from such items forbidden by the Shari'ah. Strong business ethics codes with regard to funding will augment transparency in the operations of Islamic finance institutions.

\section{CONCLUSION}

Islamic finance has been pivotal in facilitating institutions and individuals world over to engage with the financial system in ways that are consistent with the ethical Shari'ah principles (Al Rayan Bank, 2015). All the stakeholders in the society stand to benefit from the observance of ethics by one of the participants. The upholding of proper ethics has a positive multiplier effect on the affairs and the interest of other people as well as legally proper businesses. Strong adherence to business ethics by Islamic financial services providers primarily benefits these institutions over the long term. While cutting corners in the observance of business ethics may net short-term gains, unethical business practices are self-defeatist and bound to bring the errant institution on its knees eventually. The observance of business ethics in Islamic finance leads to the attainment of Maqasid al-Shari'ah that preserve and enhance the intellect, justice, and welfare of all. Non-observance of business ethics not only creates cognitive dissonance in the culprit Islamic finance institutions but also damages the public image of the industry. Since ethics in life are all-pervading, commitment to business ethics by players in Islamic finance sets an example for people in the wider society to uphold ethical virtues that leads to the advancement of the society for the good of all. The utmost upholding of business ethics in Islamic finance creates and augments harmonious relationships between depositors, owners, and professionals in the sector while at same time promoting the holistic growth of the wider society. Business ethics in Islamic finance seek to promote the success of an individual as well 
as the common good (Montgomery, 2010). Success is the end of all human activities and the purpose of human life in this world (Siddiqi, 1972).

\section{References}

Adebayo, R. I., \& Hassan, M. K. (2013). Ethical Principles of Islamic Financial Institutions. Journal of Economic Cooperation and Development, 63-90.

Ahmed, H. (2010). Defining Ethics in Islamic Finance:Looking Beyond Legality. Doha: Center for Islamic Economics and Finance.

Al Rayan Bank. (2015). Ethical Banking for Everyone. Knightsbridge: Al Rayan Bank.

Alani, F. S., \& Alani, H. K. (2012). The Role of Islamic Ethics in Accounting Environment. Journal of Business and Management, 26-30.

Alaro, A.-R. (2009). Ethics of Business in Islamic Law. The Music World League Journal, 30-35.

Ali, S. (2007). Financial Distress and Bank Failure: Relevance for Islamic Banks. Islamic banking and Finance: Fundamentals and Contemporary Issues, 99-120.

Ayub, M. (2007). Understanding Islamic Finance. West Sussex: John Wiley \& Son.

Dakhlallah, K., \& Miniaoui, H. (2011). Islamic Banks Vs. Non Islamic Ethical Dimensions. Dubai: University of Wollongong.

Delloite. (2010). Islamic Finance at Deloitte. Luxemborg: Deloitte.

Grais, W. (2004). Corporate Governance Challenges of Businesses Offering Islamic Financial Services. Washington: World Bank.

Gupta, R., \& Sukumaran, A. (2003). Ethics and Morality in Finance. Indian Journal of Management, 15-22.

Hanif, M. (2011). Differences and Similarities in Islamic and Conventional Banking. International Journal of Business and Social Science, 167-175.

Hasan, Z. (2012). Corporate Governance in Islamic Financial Institutions: An Ethical Perspective. Prime Journals of Business Administration and Management (BAM), 405-411.

Hassan, A., Chachi, A., \& Latiff, S. A. (2008). Islamic Marketing Ethics and Its Impact on Customer Satisfaction in the Islamic Banking Industry. Islamic Economics, 27-46.

IFS School of Finance. (2007). Foundations of Islamic Banking \&Finance. ISF School of Finance.

Ilias, S. (2010). Islamic Finance: Overview and Policy. Jeddah: Congressional Research Service.

Iqbal, Z. (1997). Islamic Financial Systems. Philadelphia: World Bank Publication.

IRTI. (2014). Islamic Finance. Jeddah: IRTI.

IRTI. (2016). Islamic Finance. Jeddah: IRTI.

Islamic Financial Servies Board. (2009). Guiding Principles on Conduct of Business for Institutions Offering Islamic Financial Services. Islamic Financial Services Board.

Islamic Development Bank. (2010). Islamic Finance and Global Financial Stability. Jeddah: Islamic Development Bank.

Ismail, A. G., \& Zali, N. A. (2014). Ethics in Relation to Islamic Finance Activities. Jeddah: Islamic Research and Training Institute.

Jalil, M. A., Azam, F., \& Rahman, M. K. (2010). Implementation Mechanism of Ethics in Business Organizations. International Business Research, 1-11.

Jawadi, F., Jawadi, N., \& Louhichi, W. (2014). Does Islamic Finance Outperform Conventional Finance? Further Evidence from the recent financial crisis. Paris: IPAG Business School.

Kmeid, R. (2015). Islamic Finance vs. Ethical Finance. Jeddah: A Pioneer Publication.

KPMG. (2012). Global alignment: bringing consistency to reporting of Islamic finance through IFRS. London: The Asian-Oceania standard-setter Group.

KPMG International. (2012). Global Islamic Finance \&Investments Group: Bringing the pieces together. London: KMPG International. 
Main, F., \& Mersch, Y. (2010). Prospects of Islamic finance - the view of a central bank in Europe. Luxemborg: Central Bank of Luxembourg.

Mauro, F. D., Caristi, P., Couderc, S., Maria, A. D., Ho, L., Grewal, B. K., Zaher, S. (2013). Islamic Finance in Europe. Frankfurt : European Central Bank.

Moghul, U. F. (2015). Islamic Business Ethics: Principles and Contemporary Applications Course Schedule \& Syllabus.

Montgomery, J. (2010). Ethics, Practice, and Future of Islamic Banking and Finance. Jeddah: Islamic Development Bank.

Musa, M. A. (2010). Islamic Business Ethics \& Finance: An Exploratory Study of Islamic Banks in Malaysia. Doha: Center for Islamic Economics and Finance.

Nathie, M. (2009). Islamic Bank Failure - A case study 1. Brisbane: Griffith Islamic Research Unit.

Perry, F. V., \& Rehman, S. S. (2011). Globalization of Islamic Finance: Myth or Reality? International Journal of Humanities and Social Science, 107-119.

QFinance. (2007). Business Ethics in Islamic Finance. QFinance.

Rajak, M. P. (2014). Islamic Finance: A review of its scope and prospects. International Journal of Humanities and Social Science Invention, 44-48.

Rokhman, W. (2010). The Effect of Islamic Work Ethics on Work Outcomes. Electronic Journal of Business Ethics and Organization Studies, 21-26.

Siddiqi, M. (1972). Some Aspects of the Islamic Economy. New Delhi: Ishaat-e-Islam Trust Publications.

Suzuki, Y. (2014). Islamic Economic Ethics and Japanese Traditional Business Ethics. Ritsumeikan University.

The Holy Quran.

UK Trade and Investment. (2014). UK Excellence in Islamic Finance. London: UK Trade and Investment.

Ullah, S., Jamali, D., \& Harwood, I. A. (2014). Socially Responsible Investment: Insights from Shari'a Departments in Islamic Financial Institutions. Business Ethics, 218-233.

University of Warwick. (2007). Developing Islamic Financial Markets. Coventry: University of Warwick. Usman, H., \& Malik, A. (2014). Islamic Finance: Ethics, Concepts, Practice. Jeddah: The CFA Institute Research Foundation.

Wilson, R. (1997). Islamic Finance and Ethical Investment. International Journal of Social Economics, 1325-1342.

Wilson, R. (2003). Regulatory challenges posed by Islamic capital market products and services. Durham: University of Durham.

Zerban, A., Elkady, E. H., \& Omar, R. F. (2012). Islamic Finance and Global Financial Crises: How to Keep Finance on Track? Topics in Middle Eastern and African Economies, 190-222. 